Alfred L. Daniels MD, Charles J. Coté MD, David M. Polaner MD

\title{
Continuous oxygen saturation monitoring following rectal metho- hexitone induction in paediatric patients
}

\begin{abstract}
Rectal methohexitone has been used to induce anaesthesia in paediatric patients for a number of years. This study was conducted in order to confirm the safety of this method of induction for uncomplicated routine paediatric patients. Children between the ages of six months and six years were considered candidates for induction with methohexitone $110 \%$, 25-30 $\left.\mathrm{mg} \cdot \mathrm{kg}^{-\mathrm{l}}\right)$. Patients were monitored with a continuous oxygen saturation recording. Forty-nine patients participated in this study and anaesthesia was induced successfully in 44. The mean age of the patients was $2.7 \pm 1.6 \mathrm{yr}$. The mean weight was $13.8 \pm 4.3 \mathrm{~kg}$ and the mean dose of methohexitone for successful induction was $27.0 \pm 3.0 \mathrm{mg} \cdot \mathrm{kg}^{-1}$. Continuous oximeter recordings were available in 31 of the 42 patients who allowed oximeter placement prior to administration of methohexitone. No major desaturation events were noted in any patient. Two brief episodes of desaturation occurred. One with a nadir of $90 \%$ which lasted for $45 \mathrm{sec}$ and another with a nadir of $86 \%$ which lasted for $26 \mathrm{sec}$. Both children had their heads flexed over their parents' shoulders at the time of the event resulting in partial
\end{abstract}

\section{Key words}

ANAESTHESIA: paediatric;

ANAESTHETICS, RECTAL: methohexitone;

PREMEDICATION: methohexitone;

MEASUREMENT TECHNIQUES: pulse oximetry;

MONITORING: oxygen.

From the Department of Anaesthesia, Harvard Medical School at the Massachusetts General Hospital, Boston, MA 02114.

Supported in part by an equipment grant from Nellcor, Inc., Hayward, CA 94545.

Presented in part at the Section on Anesthesiology, American Academy of Pediatrics, Seattle, WA, April, 1990.

Address correspondence to: Dr. Charles J. Coté, Department of Anesthesia, Massachusetts General Hospital, Boston, MA 02114.

Accepted for publication 29th August, 1991. airway obstruction. Both of these episodes were the result of upper airway obstruction which was clinically diagnosed by the anesthetist and readily corrected by repositioning the head. This study confirms the efficacy and safery of rectal methohexitone for induction of general anaesthesia in children. Mechanical obstruction of the ainway following induction seems to be the most likely cause for oxygen desaturation. Monitoring of pulse oximetry does not appear necessary provided the child is carefully observed for adequacy of air exchange.

Le méthohexitone par voie rectale a été utilisé pour un grand nombre d'années afin d'induire l'anesthésie chez les patients pédiatriques. Cette étude fut entreprise afin de confirmer la sécurité de cette méthode d'induction pour des patients pédiatri. ques n'ayant aucune complication. Les enfants entre l'áge de six mois et six ans furent considérés comme candidats à l'induction avec le méthohexitone $\left(10 \%, 25-30 \mathrm{mg} \cdot \mathrm{kg}^{-1}\right)$. Les patients furent surveillés avec un enregistrement continu de la saturation en oxygène. Quarante-neuf patients ont participé à cette étude et l'anesthésie fut induite avec succès chez 44 . L'âge moyen des patients était de $2,7 \pm 1,6$ ans. Le poids moyen était de 13,8 \pm $4,3 \mathrm{~kg}$ et la dose moyenne de méthohexitone pour l'induction était de $27,0 \pm 3,0 \mathrm{mg} \cdot \mathrm{kg}^{-1}$. Les enregistrements continus de l'oxymètre furent disponibles chez 31 des 42 patients chez qui on pouvait installer l'oxymètre avant l'administration de méthohexitone. Aucune saturation majeure ne fut notée chez aucun des patients. Deux épisodes brèves de désaturation sont survenues. Un avec un nadir de 90\% qui a duré 45 secondes et un autre avec un nadir de $86 \%$ qui a duré 26 sec. Les deux enfants avaient leur tête fléchie sur l'épaule des parents au moment où l'évènement est survenu à cause d'obstruction partielle des voies aériennes. Ces deux épisodes furent cliniquement diagnostiqués par l'anesthésiologiste et corrigés par le repositionnement de la tête. Cette étude confirme l'efficacité et la sécurité de l'adminis. tration rectale de méthohexitone pour l'induction de l'anesthésie générale chez les enfants. L'obstruction mécanique des voies aériennes après l'induction apparaît comme la cause la plus probable de la désaturation en oxygène. La surveillance de la saturométrie de pouls n'apparaît pas nécessaire si l'enfant est surveillé attentivement concernant l'échange gazeux adéquat. 
Administration of rectal methohexitone is a common induction technique for children between the ages of six mth and six yr. ${ }^{1-3}$ More than 20 years' experience at our institution has demonstrated an excellent although not perfect safety record. ${ }^{4}$ The purpose of this study was to evaluate objectively the safety of this induction technique by continuous monitoring of oxygen saturation following administration of rectal methohexitone.

\section{Methods}

This study was approved by the Subcommittee on Human Studies at the Massachusetts General Hospital; informed verbal consent was obtained from all parents. Study patients were selected at random from those scheduled for a variety of routine uncomplicated elective outpatient surgical procedures. The choice of rectal methohexitone induction, dose, and timing of administration was selected according to the clinical judgment of the anaesthesia team not involved in this study. In addition to an anaesthetist from the anaesthesia team or a nurse who would normally be present to observe the patient following rectal methohexitone administration, one of the investigators remained with each child to observe the patient continuously and to record events. This individual did not alter the routine anaesthetic management and did not provide oxygen saturation data to the anaesthesia team unless it was specifically requested.

Oxygen saturation and heart rate were monitored continuously using a Nellcor $\mathrm{N}-100$ pulse oximeter placed on a finger or toe and, when possible, recorded on a Nellcor N-9000 recorder. Recording was begun in the preoperative holding area prior to methohexitone administration until the children were transported to the adjacent operating rooms. The children were not monitored during the brief transport; however, an additional measurement was obtained with similar equipment upon arrival in the operating room. No oxygen or other medications were administered before or after methohexitone administration until beginning general anaesthesia.

Induction time was defined as that time when the child lost the eyelash reflex and was placed upon his/her bed before transport to the operating room. Oxygen saturation, heart rate, and sleep-awake status were recorded at baseline (before methohexitone), at the time of induction, one minute post-induction, and every five minutes thereafter until transfer into the operating room; the time from induction to leaving the holding area and the duration of transport were recorded. The strip-chart recordings and the clinical observation by one of the investigators using a stop watch quantified the duration and severity of desaturation episodes. This individual also observed the actions taken by the physician or nurse in attendance. A
TABLE Demographic data, time monitored, and saturation values in 31 patients with continuous strip chart recordings.*

\begin{tabular}{lcc}
\hline & Mean $( \pm S D)$ & Kange \\
\hline Age (yr) & $2.7 \pm 1.6$ & $7 \mathrm{mth}-6 \mathrm{yr}$ \\
Weight $(\mathrm{kg})$ & $13.8 \pm 4.3$ & $7-31 \mathrm{~kg}$ \\
Induction time (min) & $7.5 \pm 2.0$ & $4-11$ \\
Total min monitored & $23.5 \pm 5.0$ & $13-35$ \\
Baseline saturation (\%) & $98.0 \pm 0.8$ & $98-100$ \\
Saturation induction + one min & $97.6 \pm 1.2$ & $95-100$ \\
Saturation induction + five min & $97.6 \pm 1.3$ & $94-100$ \\
Saturation in operating room & $97.8 \pm 1.1$ & $95-100$ \\
\hline
\end{tabular}

* Data from I 1 other patients were not included because there was no continuous strip chart recording; however, there were no episodes of desaturation noted in these patients.

major desaturation event was defined as saturation $\leq 85 \%$ for $\geq 30 \mathrm{sec}$ or $<95 \%$ for $\geq$ one minute. . $^{5.6}$

Children often received the drug while being held in their parent's arms or while lying on their sides in a crib and then placed on their parents' laps. Standard instructions to parents included admonitions that the child's head might become "floppy" (loose muscle tone) requiring support near the time of induction. Statistical analysis consisted of calculation of means \pm SD for age, weight, drug dose, time of induction and duration of monitoring.

\section{Results}

Forty-nine patients were studied and anaesthesia was induced successfully in 44 with methohexitone. The mean age of the patients induced successfully was $2.7 \pm 1.6 \mathrm{yr}$; the mean weight was $13.8 \pm 4.3 \mathrm{~kg}$ and the mean haematocrit was $36.4 \pm 2.5 \%$. The mean dose of methohexitone was $27.0 \pm 3.0 \mathrm{mg} \cdot \mathrm{kg}^{-1}$. Two children would not allow placement of the oximeter probe before induction; anaesthesia was not induced in five children despite two doses of methohexitone. These seven patients were excluded from the data analysis. Continuous strip chart recordings were obtained from 31 of these 42 patients. Oxygen saturation data were analyzed only from those patients for whom we obtained continuous recordings although there were no desaturation events noted in any of the 11 patients who did not have continuous recordings. The mean time from drug administration until induction (loss of eyelash reflex) was $7.5 \pm 2.0 \mathrm{~min}$. The heart rate was noted to increase slightly from $120 \pm 21$ to $129 \pm 17$ bpm following methohexitone induction. The Table presents time from drug administration to induction, total time monitored, and oxygen saturation data at baseline, one and five minutes after induction, and upon arrival in the operating room.

There were no major desaturation events noted in any patient. Two brief episodes of desaturation occurred (one 
desaturation was of $45 \mathrm{sec}$ duration, nadir $90 \%$, while the other lasted $26 \mathrm{sec}$ with a nadir of $86 \%$ ). Both children had their heads flexed over their parent's shoulder at the time of the event, resulting in partial airway obstruction. Both of these episodes of desaturation were the result of partial upper airway obstruction and were clinically noted by the attending anaesthetist; both episodes of desaturation were readily corrected with repositioning of the head; however, the attending anaesthetist was unaware of the desaturation associated with this partial airway obstruction. Six other episodes of "desaturation" were associated with children crying; four of these were accompanied by heart rate and saturation recordings consistent with motion artifact. The other two appeared to be true desaturation both with a nadir of $96 \%$ and lasting less than $45 \mathrm{sec}$. No episodes of desaturation associated with crying were considered clinically important.

\section{Discussion}

The safe, psychologically atraumatic induction of anaesthesia in a paediatric patient is always a challenge for the anaesthetist. ${ }^{7}$ Rectal induction with methohexitone has proved a clinically reliable and safe method to ease the transition from the induction area to the operating room. ${ }^{1-3.7-10}$ Induction with methohexitone allows the child to fall asleep in his/her parent's arms and thus eliminates the anxiety occasionally produced by even the most skillful of inductions. This type of induction may diminish the likelihood of unpleasant memories of the operating room experience, particularly for those children who do not readily separate from their parents. The rate of successful induction in this study was similar to our previous experience. ${ }^{3}$

Recently, however, there has arisen some concern regarding the potential for airway obstruction following induction with this agent despite its long safety record. ${ }^{\text {"I }}$ The purpose of this study was to confirm our clinical impression of rectal methohexitone's overall safety and efficacy when used at a dose of $25-30 \mathrm{mg} \cdot \mathrm{kg}^{-1}$. Our study found only two minor episodes of desaturation; both were associated with partial mechanical airway obstruction. These episodes of airway obstruction were clinically recognized by the member of the anaesthesia team who had administered the medication; both were readily corrected by repositioning the head so as to provide a clear airway. The fact that two patients of 42 developed mechanical airway obstruction emphasizes the importance of careful clinical observation following deep sedation. This study suggests that although desaturation may occur following administration of rectal methohexitone, with proper supervision and care in positioning the patient, desaturation is a transient occurrence.
The period between induction and transport to the operating room is also important since head position and thus airway patency may be compromised at this point. There were no clinically apparent episodes of desaturation during transport from the induction area to the operating room; comparison of the first oxygen saturation obtained in the operating room with the last recordings made just prior to transport, revealed all to be within $1 \%$ of each other. The period of transport in this study was brief (<one $\mathrm{min}$ ) because the induction area was adjacent to the operating room.

Despite the apparent safety of this induction agent, it is our practice to have available all the means necessary to both maintain airway patency and provide oxygen and assisted ventilation, since on rare occasions there may be a very rapid uptake of agent resulting in profound sedation and central apnoea. There is also a small but finite risk of provoking seizure activity in patients with undiagnosed temporal lobe epilepsy. 4

The results of this study, using continuous oxygen saturation recordings to eliminate observer bias, confirms the efficacy and safety of rectal methohexitone for the induction of general anaesthesia in children between six months and six years of age. Mechanical obstruction of the airway following induction with rectal methohexitone seems to be the most likely cause for oxygen desaturation. Monitoring with pulse oximetry does not appear necessary provided that the child is carefully observed for adequacy of air exchange since the events in our patients were easily diagnosed clinically.

\section{References}

1 Orallo $M O$, Eather $K F$. Sodium methohexital as a rectal agent in pediatric anesthesia: a controlled comparison with sodium thiamylol. Anesth Analg 1965; 44: 97-103.

2 Liu LMP. Gaudreault P. Friedman PA, Goudsouzian NG. Liu, PL. Methohexital plasma concentrations in children following rectal administration. Anesthesiology 1985; 62: 567-70.

3 Liu LMP, Goudsouzian NG, Liu P. Rectal methohexital premedication in children, a dose comparison study. Anesthesiology 1980; 53: 343-5.

4 Rockoff $M$, Goudsouzian NG. Seizures induced by methohexital. Anesthesiology 1981;54: 333-5.

5 Coté CJ, Goldstein EA, Coté MA, Hoaglin DC, Ryan $J F$. A single-blind study of pulse oximetry in children. Anesthesiology 1988; 68: 184-8.

6 Coté CJ, Rolf N, Liu LMP et al. A single-blind study of combined pulse oximetry and capnography in children. Anesthesiology 1991; 74: 980-7.

7 Coté $C J$. Induction techniques in pediatric anesthesia. In: Barash PG (Ed.). Refresher Courses in Anesthesiology. 
The American Society of Anesthesiologists, Inc. 1989; 17: 43-57.

8 Laishley RS, $O^{\prime}$ Callaghan AC, Lerman J. Effects of dose and concentration of rectal methohexitone for induction of anaesthesia in children. Can Anaesth Soc J 1986; 33:

427-32.

9 Forbes $R B$, Vandewalker $G E$. Comparison of two and ten per cent rectal methohexitone for induction of anaesthesia in children. Can J Anaesth 1988; 35: 345-9.

10 Larsson LE, Nilsson K, Andreasson A, Ekstrom-Jodal B. Effects of rectal thiopentone and methohexitone on carbon dioxide tension in infant anaesthesia with spontaneous ventilation. Acta Anaesthesiol Scand 1987; 31: 227-30.

11 Voss $S$, Rockoff $M$, Brustowicz $R$, Caceras $A$. Oxygen saturation in children following administration of rectal methohexital (Abstract). Anesth Analg 1988; 67: S247. 